\title{
Renin Angiotensin System Components and Cancer: Reports of Association
}

\author{
Maria Del Carmen Garcia Molina Wolgien1,2, Silvana Aparecida Alves Correa ${ }^{3,4}$, \\ Pedro Alexandre Federico Breuel ${ }^{5}$, Afonso Celso Pinto Nazário', Gil Facina ${ }^{1}$ \\ ${ }^{1}$ Division of Mastology, Department of Gynecology, Federal University of Sao Paulo, Paulista School of \\ Medicine (UNIFESP-EPM), Sao Paulo, Brazil \\ ${ }^{2}$ Division of Mastology, Departament of Gynecology, Municipal Hospital and Maternity School Vila Nova \\ Cachoeirinha, Sao Paulo, Brazil \\ ${ }^{3}$ Division of Plastic Surgery, Department of Surgery, Federal University of Sao Paulo, Paulista School of \\ Medicine (UNIFESP-EPM), Sao Paulo, Brazil \\ ${ }^{4}$ Facvest University Center (UNIFACVEST), Post-Graduation Public Health Division, Lages, Santa Catarina, Brazil \\ ${ }^{5}$ Department of Teaching and Research, Municipal Hospital and Maternity School Vila Nova Cachoeirinha, Sao \\ Paulo, Brazil \\ Email: silaac@globo.com,cmolinawolgien@uol.com.br
}

Received 6 February 2016; accepted 16 May 2016; published 19 May 2016

Copyright (C) 2016 by authors and Scientific Research Publishing Inc.

This work is licensed under the Creative Commons Attribution International License (CC BY).

http://creativecommons.org/licenses/by/4.0/

(c) (i) Open Access

\section{Abstract}

Renin-Angiotensin System (RAS) is involved with hypertension and other cardiovascular diseases. However, the association of RAS components to cancer still causes suspicion. To try to clarify this, here we aimed to show this association for three important components: Angiotensin Converting Enzyme 1 (ACE1), Angiotensin Type 1 Receptor (AGTR1) and Angiotensin Type 2 Receptor (AGTR2). The first articles show that association of RAS components with cancer dates back to the 70's. ECA1 and AGTR1 have close association with cancer and ACE1 inhibitors or AGTR1 blockers are candidates to treatment of some tumors. Moreover, the action of AGTR2 is still controversial, but most studies show that the increased expression of AGTR2 can attack the cancer cells. In breast cancer, these components have also been widely studied and many works have shown that the correlation exists. Therefore specific target using these RAS components could be a beneficial, novel therapy to various tumors.

\section{Keywords}

Renin-Angiotensin System, Angiotensin Converting Enzyme, Angiotensin Type 1 Receptor, Angiotensin Type 2 Receptor, Breast Cancer, Cancer 


\section{Introduction}

The rennin-angiotensin system (RAS) and the generation of angiotensin II (Ang II) have major roles in the regulation of blood pressure and the adrenal secretion of aldosterone [1] [2]. Ang II, which is formed after conversion by Angiotensin-Converting Enzyme (ACE), acts preferentially by receptors type 1 or 2 (AGTR1 or AGTR2) [1]

The RAS plays an important role not only in homeostasis, but also in carcinogenesis. Recent epidemiological studies suggest that hypertensive patients with hyper-regulated functions of the RAS are at significantly increased risk for later development of cancer, with poor results. On the other hand, the inhibitors of RAS may reduce tumor growth, progression and metastasis [3].

Evidence suggests that Ang II possesses the role in physiological functions of the breast and that these could be modified or attenuated in cancer [4]. Furthermore, both AGTR1 and AGTR2 are mainly present in this secretory epithelium [5].

The binding of Ang II to AGTR1 induces the growth of breast cancer cells, and on the other hand triggering signaling by binding to the surface of AGTR2 causes an opposite effect, causing the growth inhibition and apoptosis [6].

Moreover, all elements of the tissue RAS (angiotensinogen, pro-renin, ACE, AGTR1, AGTR2, etc.) are present and distributed in different cell types. These results are consistent with the notion that stromal and myoepithelial elements are critical in the maintenance of normal epithelial structure and function. In illness, this system becomes disrupted, particularly in invasive carcinoma [7].

Therefore, the RAS can be involved both in normal and in abnormal physiology of the breast and other cancers. There is strong evidence that blocking the pathways of AGTR1, AGTR2 or inhibition of ACEs can have beneficial effects.

\subsection{Renin Angiotensin System and Cancer}

The effect of RAS in the pathophysiology of cancer has been analyzed and checked for almost 40 years, but the studies in past two decades have intensified. While studying the first associations of RAS components to cancer, we found that these date back to the $70 \mathrm{~s}$. Initially, the evaluations of these components were focused in the kidney and cardiovascular system, and the first type of cancer in which this association was observed was in kidney [8].

In the following decades, it has been suggested that elevated serum ACE could be implicated with a worse prognosis for lung cancer and that this enzyme could be used as a prognostic indicator in this disease [9]. In other studies, the treatment with combined Ang II showed good clinical response in the patients with advanced gastrointestinal cancer and also with breast cancer [10] [11]. Between 1985 and 1990 several works showed that RAS components were correlated with other cancers (prostate, gastric, bladder, bronchial, breast, lung and neuroblastoma) [12] [13].

The research field of correlation of RAS components to various tumor types has not ceased, but rather from the late 90s to the current date increased interest of many researchers in this area was noted. So what would be the role of these hormones and Angiotensin receptors in the initiation, promotion, progression or even specifically inhibiting mammary tumor? To answer this question, there have been many studies. The signaling cascade that involves the components of the RAS has been implicated in enhanced survival and increased proliferation of tumor cells in vitro [7] [14]-[33].

Current literature also shows the association of RAS components (AGT, ACE, angiotensin II, and AGTR1 AGTR2, etc.) to various types of cancers (Table 1), namely: breast, endometrium, ovary, lung, gastric, prostate, colorectal, bladder, etc. [34]-[44].

\subsection{Angiotensin Converting Enzyme 1 (ACE1) in Cancer}

ACE is a cell surface zinc metallopeptidase that is differentially expressed in various tumors, and plays a role in malignant cell proliferation, tumor cell migration, angiogenesis, and metastatic behavior. The effects of the ACE gene on the risk of oral cancer was suggested and it was showed that the ACE gene polymorphisms may be associated with increased susceptibility to oral precancerous lesions and oral cancer lymph node metastasis [45]. ACE polymorphisms (I/D) also would be associated with hepatocellular carcinoma (HCC), breast and endometrial cancer, indicating that the polymorphism ACE I/D would lead to progression of HCC in the Chinese population [24] [36] [46].

Moreover another studies also demonstrated association of ACE with multiple myeloma and lung cancer [47] [48]. 
Table 1. RAS components actions in different types of cancer.

\begin{tabular}{|c|c|c|}
\hline RAS COMPONENTS & ACTIONS & CANCER TYPES \\
\hline ACE1 & $\begin{array}{l}\text { Cell proliferation } \\
\text { Tumor cell migration } \\
\text { Angiogenesis } \\
\text { Metastatic behavior }\end{array}$ & $\begin{array}{l}\text { Oral } \\
\text { Hepatocellular carcinoma } \\
\text { Breast } \\
\text { Endometrial } \\
\text { Myeloma } \\
\text { Lung }\end{array}$ \\
\hline AGTR1/Ang II & $\begin{array}{l}\text { Pro-inflammatory } \\
\text { Pro-angiogenic } \\
\text { Proliferative } \\
\text { Anti-apoptotic } \\
\text { Metastatic } \\
\text { Mitogenic }\end{array}$ & $\begin{array}{l}\text { Prostate } \\
\text { Melanoma } \\
\text { Pancreatic } \\
\text { Myeloma } \\
\text { Breast }\end{array}$ \\
\hline AGTR2/Ang 1-7 & $\begin{array}{l}\text { Attenuate tumor growth } \\
\text { Correlate disease-free survival } \\
\text { Negative regulator in growth } \\
\text { Induce apoptosis }\end{array}$ & $\begin{array}{l}\text { Lung } \\
\text { Human renal clear cell carcinoma } \\
\text { Pancreatic } \\
\text { Prostate } \\
\text { Pancreatic ductal carcinoma } \\
\text { Lung adenocarcinoma } \\
\text { Leiomyoma } \\
\text { Uterinomioma }\end{array}$ \\
\hline
\end{tabular}

ACE inhibitors (ACEI) and angiotensin blockers (ARBs) may have antitumor properties. Chae et al. (2013) investigated whether the use of ACEI/ARBs affects clinical outcomes of patients with primary breast cancer who received neoadjuvant anthracycline-based and taxane. Survival outcomes were observed between users and non-users of ACE inhibitors (ACEI) or inhibitors of AGTR1 (ARB) [49].

\subsection{Angiotensin II Receptor Type 1 (AGTR1) and Cancer}

After reports of a lower prevalence of cancer in hypertensive patients receiving ACE inhibitors, the biological action of Ang II on the development or progression of cancer has been the subject of several studies. Recently, the widespread use of AGTR1 blockers has contributed more compelling information about the involvement of Ang II in carcinogenesis. Interestingly, there is growing evidence that the RAS is involved in development of various cancers. From basic and clinical data Uemura \& Kubota (2009) believe that ARBs have an ability to slow the rise of prostate specific antigen (PSA), especially in hormone-refractory cancer and suppress the incidence of prostate cancer, implying that the ARB could have a preventive activity for this cancer [50].

The AGTR1 signaling is generally pro-inflammatory, pro-angiogenic, proliferative and anti-apoptotic. And it was showed that the novel antagonist compound AGTR1 (2-(4-((2-nitro-5-propyl-1H-benzo[d]imidazol-1-yl) methyl)-1H-indol-1-yl) benzoic acid) have efficient in vitro antiproliferative and in vivo antitumor activities. Da et al. (2012) according to preliminary pharmacological characteristics observed for this compound, it was considered a candidate for the development of anticancer drugs [51]. Fujita et al. (2002) observed that another antagonist of AGTR1, the TCV-116 inhibited tumor growth, angiogenesis associated with tumors and metastases in a murine model. These results suggested that this AGTR1 antagonist inhibits angiogenesis, growth and metastasis of tumors highly dependent receptor blockade [52]. Therefore, these authors concluded that blocking the signaling AGTR1 could become an effective new strategy for cancer chemoprevention [22].

The stimulation of vascular endothelial growth factor receptor (VEGF), a transmembrane glycoprotein results in mitogenesis. Within this family of receptors, one containing the domain VEGFR 2/quinase inserted appears to be upregulated, especially during tumorigenesis. Piastowska-Ciesielska et al. (2013) showed correlation between the expression of AGTR1 and those containing VEGFR-2 kinase domain receptor in endometrial carcinoma [53].

The Ang II is involved in tumor growth, however, the exact mechanism is not known. The AGTR1 is expressed on the platelet surface, and these contribute to tumor growth. Amano et al. (2013) hypothesized that the interaction of platelets with cancer cells through AGTR1 signaling would promote the development of metastases. The results reported by these authors suggest that signaling AGTR1 play a critical role in tumor metastasis through interactions with the endothelial and tumor cells mediated by P-selectin on platelets and, through the 
production of VEGF and SDF-1 dependent of AGTR1A signaling [54].

The association of AGTR1 with several cancers was showed [55]. In prostate cancer, Ang II via AGTR1 can induce cell proliferation and show that AGTR1 blockers could be used in the treatment of prostate cancer and its chemoprevention [56] [57]. In melanoma cancer cells, the activation of AGTR1 increases the expression of metalloproteinases 2 and 13 (MMP) and also VEGF in melanoma cells. This is an important conclusion because of the great importance of these factors in the invasion of melanoma cells and the possibility of blockade of AGTR1 for the treatment of cancer [58]. In pancreatic cancer, the authors found a significant system generator of local angiotensin in these tumor cell lines, which operates of intacrina manner, that is, inside the cells. Furthermore, this Ang II produced intracellularly has aggressiveness role in the pancreatic cancer and is a potential target for therapeutic agents [59]. And finally, the AGTR1 is expressed in myeloma cells from patients with leukemia of bone marrow and possess role in the genesis of this cancer and promoting erythropoiesis [60].

\subsection{Angiotensin II Receptor Type 2 (AGTR2) and Cancer}

Despite the significant level of expression in cancer cells, the role of AGTR2 in the progression of this disease remains poorly understood. Clere et al. (2009) investigated the involvement of AGTR2 in tumorigenesis, hypothesizing a role in the proliferation and/or tumor angiogenesis. These researchers showed That AGTR2 has new mechanisms by which promotes the growth of the tumor, favoring both the proliferation of malignant cells and tumor angiogenesis [61].

In prostate cancer, the activation of AGTR2 can be associated and potentialized by the blockade of AGTR1 [62]. The AGTR2is expressed and is located in the prostate tissue and, in addition, evaluated their role in cellular morphology and number of prostatic epithelial cells in primary culture. These authors showed a decreased number of cells of non-tumor prostate after selective stimulation of the AGTR2, suggesting that this receptor may play a protective role against the development of prostate cancer. So, the use of a selective agonist AGTR2 could represent a new approach for the prevention and treatment of prostate cancer [62].

In the target gene delivery therapy, the transfection efficiency and toxicity are concerns that continue to be a challenge for this effective gene therapy [63]. In their studies of nanoparticles formulated a vector for delivery of AGTR2 gene in tumor target in the setting of intratracheal administration for therapy of lung cancer. Notably, expression of the gene in tumor tissues persisted at least 14 days after intratracheal administration. In addition, administration of this vector showed markedly attenuate tumor growth. Taken together, these results provide a proof of concept for preclinical a new gene delivery system that delivers and effective strategy for managing intratracheal gene therapy of lung cancer using the AGTR2 as target [63].

In human renal clear cell carcinoma (RCCC), it was observed that expression of AGTR2 correlated with disease-free survival. Therefore, blocking these receptors could offer directions to new anti-RCCC therapy [64].

Pancreatic cancer is one of the most aggressive human malignancies with a very poor prognosis. To assess the effect of expression of AGTR2 in the growth of carcinoma of the pancreas, Doi et al. (2010) investigated the growth of graft of pancreatic ductal carcinoma in wild-type mice deficient for either the AGTR2 (AGTR2 knockout mice, or mice with inactivated this gene). The results suggest that Ang II regulate the growth of pancreatic carcinoma cells by modulating functions of stroma cells of the host. In addition, the signaling AGTR2 functions as a negative regulator in growth of carcinoma cells in the pancreas. These results indicate that AGTR2 in stromal fibroblasts would be a potentially important for the action of chemotherapeutic agents in the treatment of pancreatic cancer target [65].

Functional AGTR2 receptors are present in prostate cancer cells and inhibit the stimulation induced by epidermal growth factor. Li et al. (2011) evaluating apoptosis of cancer cells induced by over expression of AGTR2 in the prostate. The data obtained by these authors suggest that the ability of increased expression AGTR2 induce apoptosis in prostate cancer may have therapeutic implications, and would suggest that this receptor a promising new target for gene therapy of prostate cancer [66].

Endogenous AGTR2 is capable of mediating apoptosis in cardiovascular tissues. Pickel et al. (2012) explored the anticancer effect of this receptor by its overexpression in lung adenocarcinoma cells in vitro using adenovirus (Ad), FuGENE, and nanoparticles vectors [67]. Transfection of the AGTR2 gene through nanoparticles markedly increased expression of AGTR2 and resulted in the death of A549 lung tumor cells. These results indicate that the overexpression of this receptor effectively attenuates the growth of adenocarcinoma cells through the intrinsic apoptosis. Therefore, the authors suggest that nanoparticles can be used as a vector to deliver genes 
AGTR2 and would be effective in the targeted lung adenocarcinoma therapy [67].

The AGTR2 is plentiful in the fetus and decreases rapidly after birth. The uterus expresses this receptor abundantly, even in adults, suggesting a role in reproduction. To explore the roles and regulation of AGTR2 in human uterus and to examine whether its expression is related to the characteristics of proliferation of leiomyoma [68]. Matsumoto et al. (1996) studied the expression of genes of Ang II receptors in myometrium of pregnant and nonpregnant obtained from patients undergoing gynecological surgery for uterine myoma. The receptor binding studies showed that AGTR2 agonists bind with high affinity to the receptor and are expressed in human myometrium and uterine leiomyoma [68].

\subsection{Angiotensin Converting Enzymes 1 and Angiotensin II Receptor Type 1 and 2 (ACE1 and AGTR1 and 2) in Breast Cancer}

There have indicated that RAS plays an important role at various stages of cancer progression. The presence of RAS components was shown in normal tissue and breast cancer. Insertion/deletion (I/D) polymorphism is an ACE and A1166C is a type of AGTR1 polymorphism which has been linked to various diseases such as cardiovascular diseases. Namazi et al. (2010), in their study sought to substantiate the putative importance of ACE and AGTR1 about the biology of breast. These authors investigated the influence of their genetic polymorphisms in cancer progression and showed that the polymorphism of the ACE (I/D) would associated with the expression of HER-2 and AGTR1 polymorphism (A1166C) that would associate the stage of patients with breast cancer [21].

In a recent study we conclude that changes in circulating levels of ECA1/AngIIECA2/ Ang-(1-7) determine the magnitude of the inflammatory response that an individual can trigger and the variation in ACE1 and 2 plasma level measurements in the blood of breast cancer patients suggests an association with the process of mammary carcinogenesis. Thus, is possible that RAS is associated with the process of mammary carcinogenesis by both genotypic variations of RAS components and by circulating levels of ACEs [69].

ECA1 seems to be associated with advanced stages of the disease and, on the other hand, the ACE2 seems to be more associated with the early stages, giving it a protector status against cancer. These ACEs plasma levels data here presented, combined to other recent observations that Ang-(1-7) attenuates lung cancer metastasis, has a protective effect by inhibiting cell proliferation [70] [71] and that genetic polymorphisms of the RAS components are associated with gynecological cancer risk and progression [24] [36] give another piece of evidence that the RAS may be associated with breast cancer.

Both AGTR1 and AGTR2 are present in tumors. Experimentally, acting through AGTR1AngII increases the proliferation and angiogenesis of tumor cells, and through AGTR2, inhibiting, blocking its production or function. Epidemiologic evidence on the effect of expression levels of ACE or distribution of ACE or AGTR1 variants in many cancers gives indirect support to these concepts. Furthermore, Vinson et al. (2007) believe it is possible that there is a process for the therapeutic use of high doses of ACE inhibitors and blockers AGTR1 in breast cancer, as well as by agonists can be AGTR2, although latter needs to be better investigated. Attention is called to the possibility of blocking signaling pathways mediated by AGTR1, for example, with antibodies directed against AGTR1 exploiting the possibility that the N-terminal extracellular AGTR1 may have signaling functions previously unsuspected [4].

Response rates to chemotherapy in patients with breast cancer are highly variable. De Ronde et al. (2013) studied genes associated with resistance to chemotherapy and found that among the five resistance markers identified was the AGTR1. The presence of these genes can lead to a better understanding of the mechanisms involved in resistance to chemotherapy and thereby contribute to the development of more specific and effective drugs [5].

The AGTR1 promotes tumor invasion, migration, angiogenesis and metastasis. Chen et al. (2013) explored the potential antitumor effects of AGTR1 antagonists in breast cancer [6]. These authors found that Ang II promoted cell proliferation and hyper-regulated the expression of vascular endothelial growth factor A (VEGF-A) in mammary tumor cells MCF-7. Furthermore, they found that losartan hiporregulated the expression of VEGFA in MCF-7 cells treated with Ang II. Candesartan hiporregulated the expression of VEGF-A in mice bearing xenografts of MCF-7 and inhibited tumor growth and angiogenesis. The expression of AGTR1 and VEGF-A was correlated with increased microvessel density in 102 patients with breast cancer. The data presented by these authors suggest that AGTR1 antagonists may be useful to suppress breast cancer by inhibition of Ang II [6]. 
Jethon et al. (2012) examined the correlation between the intensity of expression and the expression of the AGTR1 linfoangiogenics markers in cancers of the breast invasive ductal (IDC, invasive ductal breast cancers). These authors found a positive correlation between AGTR1 and VEGF-A and -D, which points to possible stimulatory action of Ang II expression in which may result in the increased linfoangiogenese invasive ductal breast carcinoma [72].

Chronic stress and a high fat diet are well documented risk factors associated with RAS in the development of breast cancer. Several recent studies have focused on the role of AGTR1 and cell proliferation in cancer development. Du et al. examined the hypothesis that Ang II promotes the proliferation of breast cancer cells through activation of AGTR1, which could play an important role in promoting the growth of breast cancer, and on the other hand, AGTR1 blockers inhibit proliferation by antagonizing the AGTR1. The level of AGTR1 expression was significantly hyper-regulated in breast cancer cells studied by means immunohistochemical assays but no correlation between the AGTR1 expression and the ER/PR/Her-2 expression was observed. The results obtained by these authors suggest that inhibitors of AGTR1 may be useful in using a strategy of prevention and therapy for the treatment of breast cancer [73].

With the advent of "personalized medicine" has changed profoundly the research and treatment of cancer. This individualization is paramount objective to identify the specific genetic events and/or epigenetic (that may be therapeutic targets) that direct the patient to a treatment of breast cancer differently, rather than assuming that all women with breast cancer have the same disease [74].

Ateeq et al. (2009) hypothesized that, among so many approaches in the literature, either in research on biochemical and molecular approach or in studies with genetic focus (polymorphisms), would need to assess the modulation of response AGTR1 and develop a monoclonal antibody against the extracellular domain of this receptor. Furthermore, it might be more appropriate to explore the different sites involved in AGTR1 ligand binding and transactivation of other important receptors such as the estrogen. Despite the abundant data supporting the therapeutic target this receptor, there is currently no monoclonal antibody directed to human clinical trials. In addition, these authors believe that a subgroup of patients can benefit from targeted therapy with inhibitors of AGTR1, for example, losartan. Rhodes et al. also recommend that AGTR1 antagonists may indeed be a viable therapy option for women that hiperexpressedAGTR1in breast tumors [23].

Recent studies have revealed that AGTR1 is a potential therapeutic target in breast cancer, but even then the subtype AGTR2 role in this disease has remained largely neglected. Rodrigues-Ferreira et al. (2012) described the generation and characterization of a novel cell model of human invasive breast (D3H2LN-AGTR2) that express high levels of stable human AGTR2 (Flag-hat2) cancer. These cells exhibit binding sites for high affinity Ang II. Total binding can be displaced by AGTR2 selective antagonist PD123319, but not AGTR1 antagonist, losartan selective. These investigators developed a new tool for investigating the functions of AGTR2 in breast cancer cells, regardless of activation AGTR1 [75].

\section{Conclusions}

This study shows that the action of the RAS in various cancers was investigated more than 40 years and around 20 years in breast cancer, specifically. The work presented here shows that these components, in particular ECA1, AGTR1 and AGTR2 are closely linked to cancer and can be used as targets in the fight against cancer. For this one can use ECA1 or AGTR1 blockers or potentiating actions of the AGTR2; the latter is known to be a protector against the cancer.

Therefore, we conclude that there is a correlation of these components of RAS to the cancer and the focus in the study of these components can indeed give us possibilities and solutions in development of new drugs or treatments for this very important disease that has victimized many people all over the world.

Therefore, the RAS can be involved both in the normal and in abnormal physiology of the breast and other cancers. There is strong evidence that blocking the pathways of AGTR1, AGTR2 or inhibition of ACEs can have beneficial effects.

So we can say that clinical studies on this topic will be important to confirm these evidences obtained in basic research in different populations, since it seems that the genetic and population factor, i.e. the different polymorphisms related to these genes present in the population has great influence on the prognosis and treatment of cancer. 


\section{Acknowledgements}

We thank Sao Paulo State Research Foundation (FAPESP) for the financial support.

\section{Funding}

This work was supported by the Sao Paulo State Research Foundation (FAPESP) by Grants numbers 2007/ 56480-0, 2008/50776-7, and 2008/54383-0).

\section{Conflict of Interest Statement}

None declared.

\section{References}

[1] de Gasparo, M., Catt, K.J., Inagami, T., Wright, J.W. and Unger, T. (2000) International Union of Pharmacology, XXIII. The Angiotensin II Receptors. Pharmacological Reviews, 52, 415-472.

[2] Kaschina, E. and Unger, T. (2003) Angiotensin AT1/AT2 Receptors: Regulation, Signalling and Function. Blood Pressure, 12, 70-88. http://dx.doi.org/10.1080/08037050310001057

[3] Sugimoto, M., Yamaoka, Y., Shirai, N. and Furuta, T. (2012) Role of Reninangiotensin System in Gastric Oncogenesis. Journal of Gastroenterology and Hepatology, 27, 442-451. http://dx.doi.org/10.1111/j.1440-1746.2011.06964.X

[4] Vinson, G.P., Barker, S., Puddefoot, J.R. and Tahmasebi, M. (2007) The Rennin-Angiotensin System in the Breast. In: Leung, P.S., Ed., Frontiers in Research of the Renin-Angiotensin System on Human Disease, Springer, Netherlands, 135-153.

[5] Ptasińska-Wnuk, D., Lawnicka, H., Fryczak, J., Kunert-Radek, J. and Pawlikowski, M. (2007) Angiotensin Peptides Regulate Angiogenic Activity in Rat Anterior Pituitary Tumour Cell Cultures. Endokrynologia Polska, 58, 478-486.

[6] de Ronde, J.J., Lips, E.H., Mulder, L., Vincent, A.D., Wesseling, J., Nieuwland, M., Kerkhoven, R., Vrancken Peeters, M.J., Sonke, G.S., Rodenhuis, S. and Wessels, L.F. (2013) SERPINA6, BEX1, AGTR1, SLC26A3, and LAPTM4B Are Markers of Resistance to Neoadjuvant Chemotherapy in HER2-Negative Breast Cancer. Breast Cancer Research and Treatment, 137, 213-223. http://dx.doi.org/10.1007/s10549-012-2340-X

[7] De Paepe, B., Verstraeten, V.M., De Potter, C.R. and Bullock, G.R. (2002) Increased Angiotensin II Type-2 Receptor Density in Hyperplasia, DCIS and Invasive Carcinoma of the Breast Is Paralleled with Increased iNOS Expression. Histochemistry and Cell Biology, 117, 13-19. http://dx.doi.org/10.1007/s00418-001-0356-0

[8] Tahmasebi, M., Barker, S., Puddefoot, J.R. and Vinson, G.P. (2006) Localisation of Renin-Angiotensin System (RAS) Components in Breast. British Journal of Cancer, 95, 67-74. http://dx.doi.org/10.1038/sj.bjc.6603213

[9] Leckie, B., Brown, J.J., Fraser, R., Kyle, K., Lever, A.F., Morton, J.J. and Robertson, J.I. (1978) A Renal Carcinoma Secreting Inactive Renin. Clinical science and Molecular Medicine Supplement, 4, 159s-161s. http://dx.doi.org/10.1042/cs055159s

[10] Rømer, F.K. (1981) Angiotensin-Converting Enzyme and Its Association with Outcome in Lung Cancer. British Journal of Cancer, 43, 135-142. http://dx.doi.org/10.1038/bjc.1981.21

[11] Takahashi, N., Kunii, Y., Kanno, H. and Kikuchi, K. (1982) Clinical Studies of Cancer Chemotherapy Combined with Angiotensin-II (ANG-II). Gan to Kagaku Ryoho, 9, 1640-1645.

[12] Koyama, H., Nishizawa, Y., Wada, T., Sasaki, Y., Terasawa, T., Hasegawa, Y. and Nakano, S. (1983) Effects of Angiotensin-Induced Hypertension on Cancer Chemotherapy. Application to Intra-Arterial Infusion Chemotherapy for Advanced Breast Cancer. Gan to Kagaku Ryoho, 10, 1584-1590.

[13] Mizuno, K., Ojima, M., Hashimoto, S. and Fukuchi, S. (1985) Renin and Angiotensin-Converting Enzyme in Human Neuroblastoma Tissue. Journal of Neurochemistry, 45, 626-629. http://dx.doi.org/10.1111/j.1471-4159.1985.tb04032.x

[14] Konishi, T., Kitamura, M., Suzuki, T., Mori, T., Awane, Y. and Kosaki, G. (1985) Intra-Arterial Infusion Therapy with Angiotensin II in Gastric Carcinoma. Gan to Kagaku Ryoho, 12, 1905-1914.

[15] Mc Menamin, Ú.C., Murray, L.J., Cantwell, M.M. and Hughes, C.M. (2012) Angiotensin-Converting Enzyme Inhibitors and Angiotensin Receptor Blockers in Cancer Progression and Survival: A Systematic Review. Cancer Causes Control, 23, 221-230. http://dx.doi.org/10.1007/s10552-011-9881-x

[16] Puddefoot, J.R., Udeozo, U.K., Barker, S. and Vinson, G.P. (2006) The Role of Angiotensin II in the Regulation of Breast Cancer Cell Adhesion and Invasion. Endocrine-Related Cancer, 13, 895-903.

[17] Shin, A., Cai, Q., Shu, X.O., Gao, Y.T. and Zheng, W. (2005) Genetic Polymorphisms in the Matrix Metalloproteinase 12 Gene (MMP12) and Breast Cancer Risk and Survival: The Shanghai Breast Cancer Study. Breast Cancer Research, 


\section{7, R506-R512. http://dx.doi.org/10.1186/bcr1033}

[18] Inwang, E.R., Puddefoot, J.R., Brown, C.L., Goode, A.W., Marsigliante, S., Ho, M.M., Payne, J.G. and Vinson, G.P. (1997) Angiotensin II Type 1 Receptor Expression in Human Breast Tissues. British Journal of Cancer, 75, 1279-1283. http://dx.doi.org/10.1038/bjc.1997.217

[19] George, A.J., Thomas, W.G. and Hannan, R.D. (2010) The Renin-Angiotensin System and Cancer: Old Dog, New Tricks. Nature Reviews Cancer, 10, 745-759. http://dx.doi.org/10.1038/nrc2945

[20] Mendizábal-Ruiz, A.P., Morales, J., Castro Martinez, X., Gutierrez Rubio, S.A., Valdez, L., Vásquez-Camacho, J.G., Sanchez Corona, J. and Moran Moguel, M.C. (2011) RAS Polymorphisms in Cancerous and Benign Breast Tissue. Journal of Renin-Angiotensin-Aldosterone, 12, 85-92. http://dx.doi.org/10.1177/1470320310383735

[21] Namazi, S., Monabati, A., Ardeshir-Rouhani-Fard, S. and Azarpira, N. (2010) Association of Angiotensin I Converting Enzyme (Insertion/Deletion) and Angiotensin II Type 1 Receptor (A1166C) Polymorphisms with Breast Cancer Prognostic Factors in Iranian Population. Molecular Carcinogenesis, 49, 1022-1030. http://dx.doi.org/10.1002/mc.20685

[22] Zhang, Y., He, J., Deng, Y., Zhang, J., Li, X., Xiang, Z., Huang, H., Tian, C., Huang, J. and Fan, H. (2011) The Insertion/Deletion (I/D) Polymorphism in the Angiotensin-Converting Enzyme Gene and Cancer Risk: A Meta-Analysis. BMC Medical Genetics, 12, 159. http://dx.doi.org/10.1186/1471-2350-12-159

[23] Ateeq, B., Tomlins, S.A. and Chinnaiyan, A.M. (2009) AGTR1 as a Therapeutic Target in ER-Positive and ERBB2Negative Breast Cancer Cases. Cell Cycle, 8, 3794-3795. http://dx.doi.org/10.4161/cc.8.23.9976

[24] Alves Corrêa, S.A., Ribeiro de Noronha, S.M., Nogueira-de-Souza, N.C., Valleta de Carvalho, C., Massad Costa, A.M., Juvenal Linhares, J., Vieira Gomes, M.T. and Guerreiro da Silva, I.D. (2009) Association between the Angiotensin-Converting Enzyme (Insertion/Deletion) and Angiotensin II Type 1 Receptor (A1166C) Polymorphisms and Breast Cancer among Brazilian Women. Journal of Renin-Angiotensin-Aldosterone, 10, 51-58. http://dx.doi.org/10.1177/1470320309102317

[25] Zhao, Y., Chen, X., Cai, L., Yang, Y., Sui, G. and Wu, J. (2008) Angiotensin II Suppresses Adriamycin-Induced Apoptosis through Activation of Phosphatidylinositol 3-Kinase/Akt Signaling in Human Breast Cancer Cells. Acta Biochimica et Biophysica Sinica (Shanghai), 40, 304-310. http://dx.doi.org/10.1111/j.1745-7270.2008.00402.x

[26] van der Knaap, R., Siemes, C., Coebergh, J.-W., van Duijn, C.M., Hofman, A. and Stricker, B.H. (2008) Renin-Angiotensin System Inhibitors, Angiotensin I-Converting Enzyme Gene Insertion/Deletion Polymorphism, and Cancer: The Rotterdam Study. Cancer, 112, 748-757. http://dx.doi.org/10.1002/cncr.23215

[27] Yaren, A., Turgut, S., Kursunluoglu, R., Oztop, I., Turgut, G., Degirmencioglu, S., Kelten, C. and Erdem, E. (2007) Insertion/Deletion Polymorphism of the Angiotensin I-Converting Enzyme Gene in Patients with Breast Cancer and Effects on Prognostic Factors. Journal of Investigative Medicine, 55, 255-261.

[28] Haiman, C.A., Henderson, S.O., Bretsky, P., Kolonel, L.N. and Henderson, B.E. (2003) Genetic Variation in Angiotensin I-Converting Enzyme (ACE) and Breast Cancer Risk: The Multiethnic Cohort. Cancer Research, 63, 6984-6987.

[29] Muscella, A., Greco, S., Elia, M.G., Storelli, C. and Marsigliante, S. (2002) Angiotensin II Stimulation of Na+/K+ ATPase Activity and Cell Growth by Calcium-Independent Pathway in MCF-7 Breast Cancer Cells. Journal of Endocrinology, 173, 315-323. http://dx.doi.org/10.1677/joe.0.1730315

[30] De Paepe, B., Verstraeten, V.L., De Potter, C.R., Vakaet, L.A. and Bullock, G.R. (2001) Growth Stimulatory Angiotensin II Type-1 Receptor Is Upregulated in Breast Hyperplasia and in Situ Carcinoma but Not in Invasive Carcinoma. Histochemistry and Cell Biology, 116, 247-254. http://dx.doi.org/10.1007/s004180100313

[31] Meier, C.R., Derby, L.E., Jick, S.S. and Jick, H. (2000) Angiotensin-Converting Enzyme Inhibitors, Calcium Channel Blockers, and Breast Cancer. Archives of Internal Medicine, 160, 349-353. http://dx.doi.org/10.1001/archinte.160.3.349

[32] Small Jr., W., Molteni, A., Kim, Y.T., Taylor, J.M., Ts’ao, C.-H. and Ward, W.F. (1999) Mechanism of Captopril Toxicity to a Human Mammary Ductal Carcinoma Cell Line in the Presence of Copper. Breast Cancer Research and Treatment, 55, 223-229. http://dx.doi.org/10.1023/A:1006233521325

[33] Tahmasebi, M., Puddefoot, J.R., Inwang, E.R., Goode, A.W., Carpenter, R. and Vinson, G.P. (1998) Transcription of the Prorenin Gene in Normal and Diseased Breast. European Journal of Cancer, 34, 1777-1782. http://dx.doi.org/10.1016/S0959-8049(98)00173-7

[34] Fishchuk, L.E. and Gorovenko, N.G. (2013) Genetic Polymorphisms of the Renin-Angiotensin System in Breast Cancer Patients. Experimental Oncology, 35, 101-104.

[35] Ladd, A.M., Vasquez, A.A., Siemes, C., Yazdanpanah, M., Coebergh, J.W., Hofman, A., Stricker, B.H. and van Duijn, C.M. (2007) Differential Roles of Angiotensinogen and Angiotensin Receptor Type 1 Polymorphisms in Breast Cancer Risk. Breast Cancer Research and Treatment, 101, 299-304. http://dx.doi.org/10.1007/s10549-006-9290-0

[36] Correa-Noronha, S.A., Ribeiro de Noronha, S.M., Alecrim, C., Mesquita, A.D., Brito, G.S., Junqueira, M.G., Leite, D.B., Carvalho, C.V. and Silva, I.D. (2012) Association of Angiotensin-Converting Enzyme I Gene I/D Polymorphism 
with Endometrial but Not with Ovarian Cancer. Gynecological Endocrinology, 28, 889-891. http://dx.doi.org/10.3109/09513590.2012.683060

[37] Song, L., Zhang, S.L., Bai, K.H., Yang, J., Xiong, H.Y., Li, X., Liu, T. and Liu, H.R. (2013) Serum Agonistic Autoantibodies against Type-1 Angiotensin II Receptor Titer in Patients with Epithelial Ovarian Cancer: A Potential Role in Tumor Cell Migration and Angiogenesis. Journal of Ovarian Research, 6, 22. http://dx.doi.org/10.1186/1757-2215-6-22

[38] Qian, Y.R., Guo, Y., Wan, H.Y., Fan, L., Feng, Y., Ni, L., Xiang, Y. and Li, Q.Y. (2013) Angiotensin-Converting Enzyme 2 Attenuates the Metastasis of Non-Small Cell Lung Cancer through Inhibition of Epithelial-Mesenchymal Transition. Oncology Reports, 29, 2408-2414.

[39] Rinsho, N. (2012) [Renin-Angiotensin System (RAS) as New Molecular Therapeutic Targets in Prostate Cancer]. Nihon Rinsho. Japanese Journal of Clinical Medicine, 70, 1604-1612.

[40] Kuniyasu, H. (2012) Multiple Roles of Angiotensin in Colorectal Cancer. World Journal of Clinical Oncology, 3, 150-154.

[41] Yuge, K., Miyajima, A., Tanaka, N., Shirotake, S., Kosaka, T., Kikuchi, E. and Oya, M. (2012) Prognostic Value of Renin-Angiotensin System Blockade in Non-Muscle-Invasive Bladder Cancer. Annals of Surgical Oncology, 19, 39873993. http://dx.doi.org/10.1245/s10434-012-2568-z

[42] Stoll, M. and Unger, T. (2001) Angiotensin and Its $\mathrm{AT}_{2}$ Receptor: New Insights into an Old System. Regulatory Peptides, 99, 175-182. http://dx.doi.org/10.1016/s0167-0115(01)00246-4

[43] Thomas, W.G. and Mendelsohn, F.A.O. (2003) Molecules in Focus Angiotensin Receptors: Form and Function and Distribution. The International Journal of Biochemistry \& Cell Biology, 35, 774-779. http://dx.doi.org/10.1016/S1357-2725(02)00263-7

[44] Wen, S.W., Ager, E.I., Neo, J. and Christophi, C. (2013) The Renin Angiotensin System Regulates Kupffer Cells in Colorectal Liver Metastases. Cancer Biology \& Therapy, 14, 720-727. http://dx.doi.org/10.4161/cbt.25092

[45] Liu, Y.T., Lin, L.W., Chen, C.Y., Wang, C.P., Liu, H.P., Houng, J.Y., Chung, F.M. and Shieh, T.Y. (2012) Polymorphism of Angiotensin I-Converting Enzyme Gene Is Related to Oral Cancer and Lymph Node Metastasis in Male Betel Quid Chewers. Oral Oncology, 48, 1257-1262. http://dx.doi.org/10.1016/j.oraloncology.2012.06.003

[46] Yuan, F., Zhang, L.-S., Li, H.-Y., Liao, M., Lv, M. and Zhang, C. (2013) Influence of Angiotensin I-Converting Enzyme Gene Polymorphism on Hepatocellular Carcinoma Risk in China. DNA and Cell Biology, 32, 268-273. http://dx.doi.org/10.1089/dna.2012.1910

[47] Albayrak, M., Celebi, H., Albayrak, A., Sayilir, A., Yesil, Y., Balcik, O.S., Yokus, O. and Celik, T. (2012) Elevated Serum Angiotensin Converting Enzyme Levels as a Reflection of Bone Marrow Renin-Angiotensin System Activation in Multiple Myeloma. Journal of Renin-Angiotensin-Aldosterone, 13, 259-264. http://dx.doi.org/10.1177/1470320312437070

[48] Dević Pavlić, S., Ristić, S., Flego, V., Kapović, M. and Radojčić Badovinac, A. (2012) Angiotensin-Converting Enzyme Insertion/Deletion Gene Polymorphism in Lung Cancer Patients. Genetic Testing and Molecular Biomarkers, 16, 722-725. http://dx.doi.org/10.1089/gtmb.2011.0306

[49] Chae, Y.K., Brown, E.N., Lei, X., Melhem-Bertrandt, A., Giordano, S.H., Litton, J.K., Hortobagyi, G.N., Gonzalez-Angulo, A.M. and Chavez-Macgregor, M. (2013) Use of ACE Inhibitors and Angiotensin Receptor Blockers and Primary Breast Cancer Outcomes. Journal of Cancer, 4, 549-556. http://dx.doi.org/10.7150/jca.6888

[50] Uemura, H. and Kubota, Y. (2009) [Role of Renin-Angiotensin System in Prostate Cancer]. Gan to Kagaku Ryoho. Cancer \& Chemotherapy, 36, 1228-1233.

[51] Da, Y.J., Yuan, W.D., Zhu, L.F. and Chen, Z.L. (2012) Synthesis, Anti-Hypertensive Effect of a Novel Angiotensin II $\mathrm{AT}_{1}$ Receptor Antagonist and Its Anti-Tumor Activity in Prostate Cancer. Arzneimittelforschung, 62, 637-643. http://dx.doi.org/10.1055/s-0032-1329952

[52] Fujita, M., Hayashi, I., Yamashina, S., Itoman, M. and Majima, M. (2002) Blockade of Angiotensin AT1a Receptor Signaling Reduces Tumor Growth, Angiogenesis, and Metastasis. Biochemical and Biophysical Research Communications, 294, 441-447. http://dx.doi.org/10.1016/S0006-291X(02)00496-5

[53] Piastowska-Ciesielska, A.W., Płuciennik, E., Wójcik-Krowiranda, K., Bieńkiewicz, A., Nowakowska, M., Pospiech, K., Bednarek, A.K., Domińska, K. and Ochędalski, T. (2013) Correlation between VEGFR-2 Receptor Kinase Domain-Containing Receptor (KDR) mRNA and Angiotensin II Receptor Type 1 (AT1-R) mRNA in Endometrial Cancer. Cytokine, 61, 639-644. http://dx.doi.org/10.1016/j.cyto.2012.11.017

[54] Amano, H., Ito, Y., Ogawa, F., Eshima, K., Suzuki, T., Oba, K., Matsui, Y., Kato, S., Fukui, T., Nakamura, M., Kitasato, H., Fukamizu, A. and Majima, M. (2013) Angiotensin II Type 1A Receptor Signaling Facilitates Tumor Metastasis Formation through P-Selectin-Mediated Interaction of Tumor Cells with Platelets and Endothelial Cells. American Journal of Pathology, 182, 553-564. http://dx.doi.org/10.1016/j.ajpath.2012.10.026 
[55] Uemura, H. and Kubota, Y. (2012) [Cancer and Renin-Angiotensin System]. Nihon Rinsho. Japanese Journal of Clinical Medicine, 70, 1530-1535.

[56] Domińska, K., Piastowska-Ciesielska, A.W., Lachowicz-Ochędalska, A. and Ochędalski, T. (2012) Similarities and Differences between Effects of Angiotensin III and Angiotensin II on Human Prostate Cancercell Migration and Proliferation. Peptides, 37, 200-206. http://dx.doi.org/10.1016/i.peptides.2012.07.022

[57] Uemura, H., Hoshino, K. and Kubota, Y. (2011) Engagement of Renin-Angiotensin System in Prostate Cancer. Current Cancer Drug Targets, 11, 442-450. http://dx.doi.org/10.2174/156800911795538101

[58] Akhavan, M.M., Karimi, M., Ghodrati, M. and Falahtpishe, H. (2011) AT 1 Receptors Activation Enhances the Expression of MMP-2, MMP-13 and VEGF but not MMP-9 in B16F10 Melanoma Cells. Pakistan Journal of Biological Sciences, 14, 821-830. http://dx.doi.org/10.3923/pjbs.2011.821.830

[59] Pérez-Díaz, I., Guzmán, C., Olivares-Reyes, J.A., Ramírez, T., Gutierréz-Reyes, G., Hiriart, M. and Robles-Díaz, G. (2011) Evidence of an Intracellular Angiotensin-Generating System and Non-AT 1 , Non- $\mathrm{AT}_{2}$ Binding Site in a Human Pancreatic Cell Line. Pancreas, 40, 701-707. http://dx.doi.org/10.1097/MPA.0b013e318215a891

[60] Peng, M.Y., Wang, L.L., Liang, T., Zhao, X.L., Wang, G.P. and Chen, F.P. (2010) Expression of Angiotensin-II Type 1 Receptor $\mathrm{AT}_{1}$ mRNA in Myeloid Leukemia. Journal of Experimental Hematology, 18, 1418-1421.

[61] Clere, N., Corre, I., Faure, S., Guihot, A.L., Vessières, E., Chalopin, M., Morel, A., Coqueret, O., Hein, L., Delneste, Y., Paris, F. and Henrion, D. (2010) Deficiency or Blockade of Angiotensin II Type 2 Receptor Delays Tumorigenesis by Inhibiting Malignant Cell Proliferation and Angiogenesis. International Journal of Cancer, 127, 2279-2291. http://dx.doi.org/10.1002/ijc.25234

[62] Guimond, M.O., Battista, M.C., Nikjouitavabi, F., Carmel, M., Barres, V., Doueik, A.A., Fazli, L., Gleave, M., Sabbagh, R. and Gallo-Payet, N. (2013) Expression and Role of the Angiotensin II $\mathrm{AT}_{2}$ Receptor in Human Prostate Tissue: In Search of a New Therapeutic Option for Prostate Cancer. The Prostate, 73, 1057-1068. http://dx.doi.org/10.1002/pros.22653

[63] Kawabata, A., Baoum, A., Ohta, N., Jacquez, S., Seo, G.M., Berkland, C. and Tamura, M. (2012) Intratracheal Administration of a Nanoparticle-Based Therapy with the Angiotensin II Type 2 Receptor Gene Attenuates Lung Cancer Growth. Cancer Research, 72, 2057-2067. http://dx.doi.org/10.1158/0008-5472.CAN-11-3634

[64] Dolley-Hitze, T., Jouan, F., Martin, B., Mottier, S., Edeline, J., Moranne, O., Le Pogamp, P., Belaud-Rotureau, M.A., Patard, J.J., Rioux-Leclercq, N. and Vigneau, C. (2010) Angiotensin-2 Receptors (AT1-R and AT2-R), New Prognostic Factors for Renal Clear-Cell Carcinoma? British Journal of Cancer, 103, 1698-1705. http://dx.doi.org/10.1038/sj.bjc.6605866

[65] Doi, C., Egashira, N., Kawabata, A., Maurya, D.K., Ohta, N., Uppalapati, D., Ayuzawa, R., Pickel, L., Isayama, Y., Troyer, D., Takekoshi, S. and Tamura, M. (2010) Angiotensin II Type 2 Receptor Signaling Significantly Attenuates Growth of Murine Pancreatic Carcinoma Grafts in Syngeneic Mice. BMC Cancer, 10, 67. http://dx.doi.org/10.1186/1471-2407-10-67

[66] Li, H., Qi, Y., Li, C., Braseth, L.N., Gao, Y., Shabashvili, A.E., Katovich, M.J. and Sumners, C. (2009) Angiotensin Type 2 Receptor-Mediated Apoptosis of Human Prostate Cancer Cells. Molecular Cancer Therapeutics, 8, 3255-3265. http://dx.doi.org/10.1158/1535-7163.MCT-09-0237

[67] Pickel, L., Matsuzuka, T., Doi, C., Ayuzawa, R., Maurya, D.K., Xie, S.X., Berkland, C. and Tamura, M. (2010) OverExpression of Angiotensin II Type 2 Receptor Gene Induces Cell Death in Lung Adenocarcinoma Cells. Cancer Biology \& Therapy, 9, 277-285. http://dx.doi.org/10.4161/cbt.9.4.10643

[68] Matsumoto, T., Sagawa, N., Mukoyama, M., Tanaka, I., Itoh, H., Goto, M., Itoh, H., Horiuchi, M., Dzau, V.J., Mori, T. and Nakao, K. (1996) Type 2 Angiotensin II Receptor Is Expressed in Human Myometrium and Uterine Leiomyoma and Is Down-Regulated during Pregnancy. The Journal of Clinical Endocrinology and Metabolism, 81, 4366-4372.

[69] Wolgien, M.C.G.M., Silva, I.D.C.G., Nazário, A.C.F., Nakaie, C.R., Noronha, S.A.A.C., Ribeiro de Noronha, S.M. and Facina, G. (2013) Plasma Levels of Angiotensin-Converting Enzymes 1 and 2 and AGTR2 (T1247G and A5235G) Gene Polymorphisms Are Associated to Breast Cancer Progression. Journal of Cancer Therapy, 4, 1403-1410. http://dx.doi.org/10.4236/jct.2013.49167

[70] Noronha, S.A.A.C., Bernardo,W., Barros, A.J., Nakaie, C.R., Shimuta, S.I., Silva, I.D.C.G. and Noronha, S.M.R. (2013) Effects on Cell Viability and on Apoptosis in Tumoral (MCF-7) and in Normal (MCF10A) Epithelial Breast Cells after Human Chorionic Gonadotropin and Derivated-Angiotensin Peptides Treatments. Journal of Cancer Therapy, 4, 65-69. http://dx.doi.org/10.4236/jct.2013.47A010

[71] Binda Neto, I., Noronha, S.M.R., Noronha, S.A.A.C., Wolgien, M.D.C. M., Barros, A.J., Nakaie, C.R., Shimuta, S.I., Facina, G. and Silva, I.D.C.G. (2013) Angiotensin-(1 - 7) and Human Chorionic Gonadotropin (hCG) Modulate the Nuclear Transcription Factors or Nuclear Receptors Genes in the Tumorigenic Undifferentiated Breast Cancer Cell Line SKBR3. Journal of Cancer Therapy, 4, 70-74. http://dx.doi.org/10.4236/jct.2013.47A011 
[72] Jethon, A., Pula, B., Piotrowska, A., Wojnar, A., Rys, J., Dziegiel, P. and Podhorska-Okolow, M. (2012) Angiotensin II Type 1 Receptor $(A T-1 R)$ Expression Correlates with VEGF-A and VEGF-D Expression in Invasive Ductal Breast Cancer. Pathology \& Oncology Research, 18, 867-873. http://dx.doi.org/10.1007/s12253-012-9516-X

[73] Du, N., Feng, J., Hu, L.J., Sun, X., Sun, H.B., Zhao, Y., Yang, Y.P. and Ren, H. (2012) Angiotensin II Receptor Type 1 Blockers Suppress the Cell Proliferation Effects of Angiotensin II in Breast Cancer Cells by Inhibiting AT1R Signaling. Oncology Reports, 27, 1893-1903.

[74] Tursz, T., Andre, F., Lazar, V., Lacroix, L. and Soria, J.C. (2011) Implications of Personalized Medicine-Perspective from a Cancer Center. Nature Reviews Clinical Oncology, 8, 177-183. http://dx.doi.org/10.1038/nrclinonc.2010.222

[75] Rodrigues-Ferreira, S., Abdelkarim, M., Dillenburg-Pilla, P., Luissint, A.C., di-Tommaso, A., Deshayes, F., Pontes, C.L., Molina, A., Cagnard, N., Letourneur, F., Morel, M., Reis, R.I., Casarini, D.E., Terris, B., Couraud, P.O., Costa-Neto, C.M., Di, Benedetto, M. and Nahmias, C. (2012) Angiotensin II Facilitates Breast Cancer Cell Migration and Metastasis. PLoS ONE, 7, e35667. http://dx.doi.org/10.1371/journal.pone.0035667 